\title{
RANCANG BANGUN APLIKASI BOOKING LAPANGAN FUTSAL PADA KEVIN FUTSAL BERBASIS ANDROID
}

\author{
Muhamad Fikri Paturahman', Verdi Yasin ${ }^{2}$, Rachmawaty Haroen ${ }^{3}$ \\ Program Studi Teknik Informatika, STMIK Jayakarta ${ }^{1}$, Program Studi Teknik Informatika, STMIK \\ Jayakarta ${ }^{2}$, Program Studi Teknik Informatika, STMIK Jayakarta ${ }^{3}$ \\ Fikripaturahman23@gmail.com ${ }^{1}$, verdiyasin29@gmail.com ${ }^{2}, \underline{\text { rachmawatyharoen@gmail.com }}{ }^{3}$
}

Received: 2021-02-20, Revised: 2021-03-25, Accepted: 2021-03-30

\begin{abstract}
Abstrak
Tekonologi semakin berkembang dan maju pada saat ini sudah tidak terpungkiri lagi. Kemajuan teknologi saat ini yaitu android yang membawa dampak positif dan canggih sehingga dapat meningkatkan kualitas dalam mengembangkan usaha kepada konsumen. Pada sistem penyewaan lapangan futsal saat ini masih menggunakan sistem manual yang dirasa kurang efektif dan efisien karena dapat menyita banyak waktu dalam pemesanan lapangan futsal. Oleh sebab itu, penulis bermaksud untuk merancang suatu sistem aplikasi yang mempermudah proses dalam penyewaan lapangan futsal. Sistem aplikasi ini dibuat agar pemesan dapat melakukan proses penyewaan melalui online tanpa harus mendatangi lokasi lapangan terlebih dahulu, sistem aplikasi ini juga dapat memperlihatkan jadwal lapangan yang masih tersedia.Penelitian ini dibangun dengan metode pengembangan sistem SDLC dengan model Waterfall,untuk permodelan sistem menggunakan UML (Unified Modeling Language) serta perangkat lunnak yang digunakan dalam membangun sistem ini menggunakan bahasa pemrograman JAVA.Metode pengumpulan data yaitu metode observasi, wawancara dan studi Pustaka.Hasil dari penelitian ini menunjukkan bahwa penggunaan aplikasi booking berbasis android ini dapat memudahkan dalam proses pemesanan.
\end{abstract}

Kata kunci: Perancangan , Android, Futsal, Waterfall, Sistem Booking.

\begin{abstract}
Technology is growing and advancing at this time it is undeniable. Current technological advances, namely Android, have a positive and sophisticated impact so that they can improve quality in developing businesses for consumers. The futsal field rental system currently still uses a manual system which is considered less effective and efficient because it can take up a lot of time in ordering futsal fields. Therefore, the author intends to design an application system that facilitates the process of renting a futsal field. This application system is made so that the customer can make the rental process online without having to go to the field location first, this application system can also show the available field schedules. This research was built using the SDLC system development method with the Waterfall model, for system modeling using UML (Unified Modeling Language) and the software used in building this system uses the JAVA programming language. The data collection methods are observation, interviews and Pustaka studies. The results of this study indicate that the use of this android-based booking application can facilitate the ordering process.
\end{abstract}

Keywords: design, Android, Futsal, Waterfall, Booking system.

\section{Pendahuluan (or Introduction)}

Futsal adalah olahraga yang banyak diminati oleh semua kalangan, futsal berasal dari Bahasa Spanyol dari kata Futbol (sepak bola) dan Sala (kamar) ketika digabungkan menjadi sepak bola dalam ruangan. Olahraga ini dapat dilakukan di lapangan terbuka maupun tertutup dengan Panjang 38-42 meter dan lebar 15-25 meter dan dimainkan oleh 5 pemain dalam satu tim. Kevin 
Futsal merupakan salah satu tempat di Jakarta yang meyediakan penyewaan lapangan futsal.

Pada era tekonologi yang semakin berkembang dan maju saat ini memang sudah tidak bisa terpungkiri lagi. Salah satu kemajuan teknologi pada saat ini yaitu Android yang membawa dampak energi positif dikarenakan dapat memberikan variasi baru dan lebih canggih sehingga dapat meningkatkan kualitas suatu perusahaan dalam mengembangkan usaha kepada konsumen. Menurut Akhmad Dharma Kasman (2016:2) pada kutipan yang diambil [1], "Android adalah sebuah sistem operasi telepon seluler dan komputer tablet layar sentuh (touchscreen) yang berbasis linux." Namun seiring perkembangannya, android berubah menjadi platform yang begitu cepat dala malakukan inovasi, Sedangkan menurut (Hozeng and Syam 2017) pada kutipan jurnal [2] Android adalah sistem operasi yang berbasis Linux untuk telepon seluler seperti telepon pintar dan komputer tablet.

Kemajuan itu juga terdapat dalam olahraga futsal yang mempengaruhi sistem penyewaan. Pada saat ini sistem penyewaan lapangan futsal masih menggunakan sistem manual yang dirasa kurang efektif dan efisien karena dapat menyita banyak waktu dalam pemesanan lapangan futsal. Oleh sebab itu, penulis bermaksud untuk merancang suatu sistem aplikasi yang mempermudah proses dalam penyewaan lapangan futsal. Sistem aplikasi ini dibuat agar pemesan dapat melakukan proses penyewaan melalui online tanpa harus mendatangi lokasi lapangan terlebih dahulu, sistem aplikasi ini juga dapat memperlihatkan jadwal lapangan yang masih tersedia.

Kevin Futsal masih menggunakan sistem manual dalam proses penyewaan lapangan yang dimana penyewa harus mendatangi lapangan terlebih dahulu untuk menanyakan jadwal yang tersedia. Dengan adanya kemajuan teknologi Android, penulis berencana membuatkan sebuah "Rancang Bagun Aplikasi Booking Lapangan Futsal berbasis Android Pada Kevin Futsal" dengan tujuan untuk memudahkan dalam menyesuaikan jadwal calon penyewa dengan daftar lapangan yang masih tersedia tanpa harus menghubungi pihak Kevin Futsal dan menanyakan langsung kepada karyawan Kevin Futsal yang bertugas.

\section{Tinjauan Literatur (or Literature Review)}

A. Android

Android adalah sebuah sistem operasi untuk perangkat mobile berbasis linux yang mencakup sis-tem operasi, middleware dan aplikasi. Android me-nyediakan platform terbuka bagi para pengembang untuk menciptakan aplikasi mereka. Android adalah sistem operasi yang dikembangkan untuk perangkat mobile berbasis linux. Sistem operasi ini biasanya ditanamkan pada smartphone atau komputer tablet. Seperti halnya linux, android merupakan sistem operasi opensource, itu artinya android menyediakan kebebasan bagi para pengembang untuk mencip-takan aplikasi mereka sendiri yang bisa digunakan oleh macam-macam piranti bergerak (mobile devide).

B. Sistem Operasi Mobile

Menurut [3] sistem operasi mobile adalah software utama yang melakukan manajemen dan kontrol terhadap hardware secara langsung serta manajemen dan mengontrol softwaresoftware lain sehingga software-software lain tersebut dapat bekerja. Sehingga suatu sistem operasi mobile akan bertanggung jawab dalam mengoperasikan berbagai fungsi dan fitur yang tersedia dalam perangkat ponsel tersebut seperti, schedulling task, keyboard, WAP, email, text message, sinkronisasi dengan aplikasi dan perangkat lain, memutar musik, kamera, dan mengontrol fitur-fitur lainnya .

Berikut ini adalah beberapa sistem operasi yang sudah umum, antara lain:

1. Windows Mobile

Windows Mobile adalah sistem operasi mobile yang beroperasi pada platform perangkat Windows Mobile.

2. IOS 
IOS adalah sistem operasi keluaran dari Apple yang digunakan dalam semua lini gadgetnya yaitu Iphone, Ipad, \& Ipod.

3. Android

Android adalah salah satu dari sistem operasi open source yang terkenal di kalangan masyarakat. Desain dari sistem operasi Android bisa disesuaikan dengan operator dan produsen perangkat mobile yang ingin menggunakannya.

4. Blackberry

Blackberry merupakan sistem operasi besutan RIM yang populer pada tahun 2008 dengan aplikasi chat blackberry messenger.

\section{Android Studio}

Android Studio merupakan sebuah Integrated Development Environment (IDE) khusus untuk membangun aplikasi yang berjalan pada platform android. Android studio ini berbasis pada IntelliJ IDEA, sebuah IDE untuk bahasa pemrograman Java. Bahasa pemrograman utama yang digunakan adalah Java, 12 sedangkan untuk membuat tampilan atau layout, digunakan bahasa XML.Android studio juga terintegrasi dengan Android Software Development Kit (SDK) untuk deploy ke perangkat android. Android Studio juga merupakan pengembangan dari eclipse, dikembangkan menjadi lebih kompleks dan professional yang telah tersedia didalamnya Android Studio IDE, Android SDK tools (Google Android Studio, 2016).

D. Java Development Kit

Menurut DeCoster (2012) dalam jurnal Aplikasi Edukasi Budaya Toba Samosir Berbasis Android [4], Java adalah sebuah teknologi yang diperkenalkan oleh Sun Microsystems pada pertengahan tahun 1990. definisi Sun, Java adalah nama untuk sekumpulan teknologi untuk membuat dan menjalankan perangkat lunak pada komputer standalone ataupun pada lingkungan jaringan. membuat program Java dibutuhkan compiler dan debugger untuk program Java berbentuk Java Development Kit (JDK) yang diproduksi oleh Sun Microsystems. Sebelum memulai instalasi Android SDK, terlebih dahulu kita harus melakukan instalasi JDK di komputer.

E. Metode Waterfall

Metode Waterfall adalah salah satu jenis model pengembangan aplikasi dan termasuk ke dalam classic life cycle (siklus hidup klasik), yang mana menekankan pada fase yang berurutan dan sistematis. Untuk model pengembangannya, dapat dianalogikan seperti air terjun, dimana setiap tahap dikerjakan secara berurutan mulai dari atas hingga ke bawah. [5]

\section{Metode Penelitian (or Research Method)}

A. Tempat dan Waktu Penelitian

Penelitian ini penulis lakukan bertempatan di Kevin Futsal yang berlokasi di Jl. Kramat II No.17, RT.1/RW.8, Kwitang, Senen, Kota Jakarat Pusat.

Tabel 1 Waktu Penelitian

\begin{tabular}{|c|c|c|c|c|c|c|c|c|c|c|c|c|c|c|c|c|}
\hline $\begin{array}{c}\text { Jadwal } \\
\text { Kegiatan }\end{array}$ & \multicolumn{16}{|c|}{$\begin{array}{l}\text { Bulan } \\
\text { Kegiatan }\end{array}$} \\
\hline & \multicolumn{4}{|c|}{ Maret } & \multicolumn{4}{|c|}{ April } & \multicolumn{4}{|c|}{ Mei } & \multicolumn{4}{|c|}{ Juni } \\
\hline & 1 & 2 & 3 & 4 & 1 & 2 & 3 & 4 & 1 & 2 & 3 & 4 & 1 & 2 & 3 & 4 \\
\hline $\begin{array}{l}\text { Mentukan } \\
\text { Lokasi } \\
\text { Penelitian }\end{array}$ & & & & & & & & & & & & & & & & \\
\hline $\begin{array}{l}\text { Pengajuan } \\
\text { Penelitian }\end{array}$ & & & & & & & & & & & & & & & & \\
\hline
\end{tabular}


Volume 2, Nomor 1, April 2021, halaman 60-74

https://jurnal.amikwidyaloka.ac.id/index.php/awl jurnal@amikwidyaloka.ac.id / editor.jurnalwidya@gmail.com

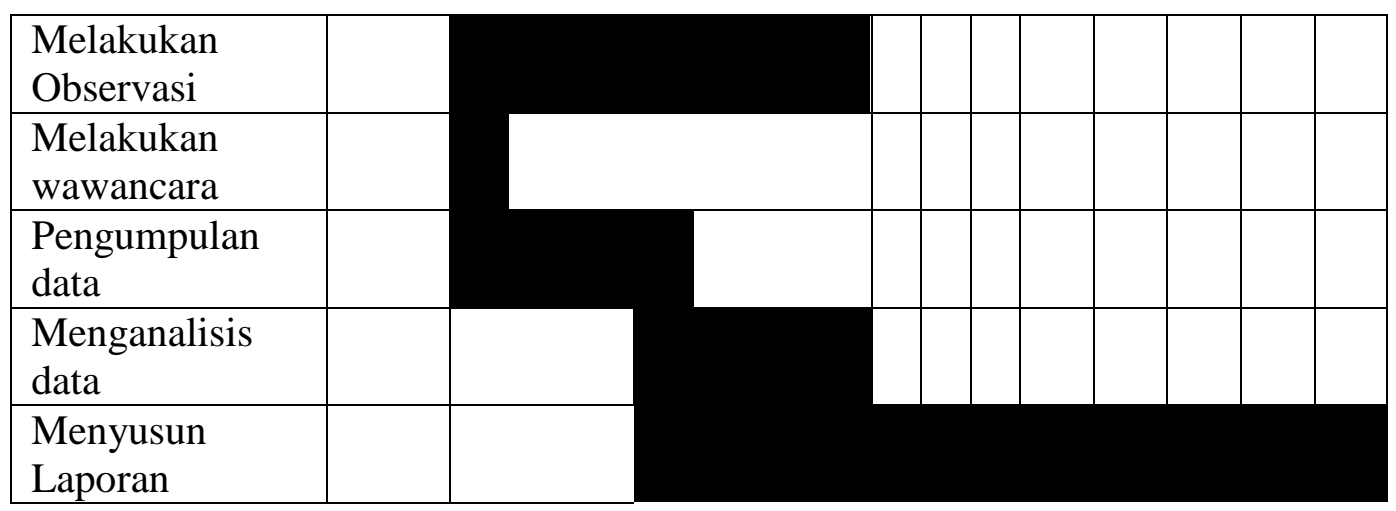

B. Paradigma Penelitian

Paradigma penelitian menggambarkan pilihan suatu kepercayaan yang akan mendasari dan memberi pedoman seluruh proses penelitian, paradigma penelitian menentukan masalah apa yang dituju dan tipe penjelasan apa yang diterimanya.

1. Kronologi Penelitian

Sistem booking yang saat ini digunakan di Kevin Futsal. Selama ini untuk melakukan booking lapangan futsal masih menggunakan cara lama yaitu dengan cara datang langsung dan menanyakan jadwal lapangan yang ingin digunakan dalam pencatatan jadwal lapangan dan pembooking yang ingin bermain masih menggunakan buku sehingga kurang efisien dan efektif.

\section{Model Yang Akan Dikembangkan}

Model yang akan digunakan untuk perancangan sistem booking lapangan futsal ini adalah Waterfall. Model ini digunakan karena kebutuhan aplikasi yang sesuai dengan sistem yang berjalan. Model waterfall digambarkan sebagai berikut:

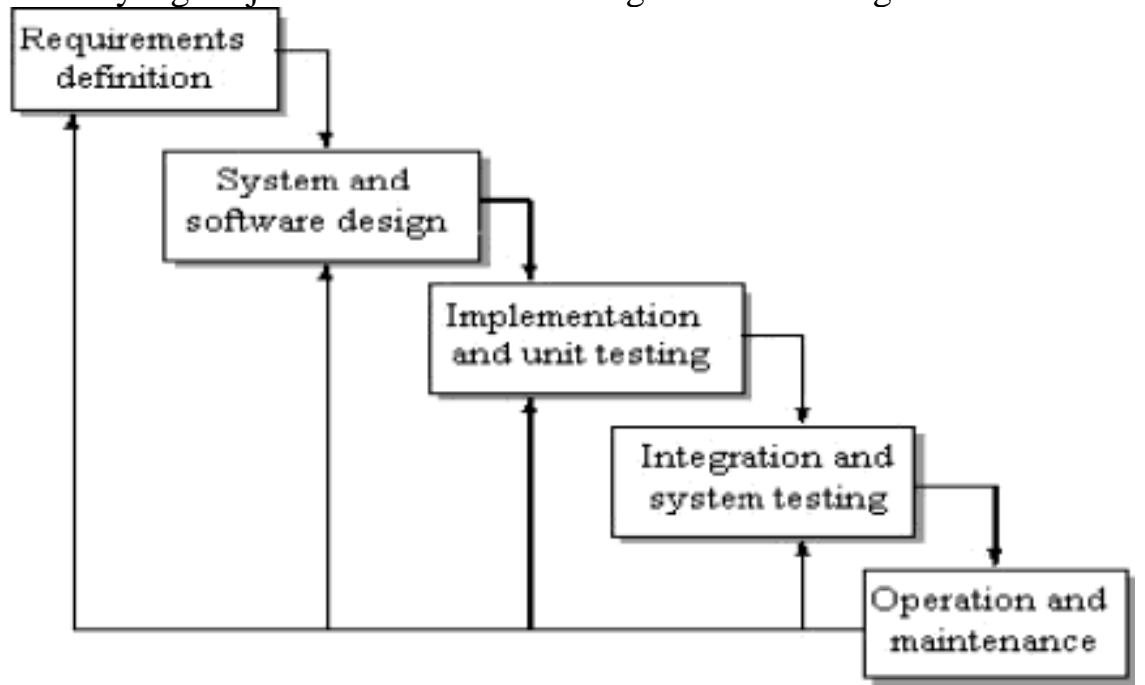

Gambar 1. Model Waterfall

Berikut adalah tahapan perancangan sistem yang dilakukan dengan menggunakan model waterfall :

a) Analisis Kebutuhan

Kebutuhan yang didapatkan dari hasil wawancara dengan Penjaga dan Karyawan di Kevin Futsal dianalisa untuk mendapatkan kebutuhan aplikasi. Kebutuhan aplikasi ini kemudian dijadikan referensi untuk merancang aplikasi. 
b) Desain

Tahap design digunakan untuk menerjemahkan kebutuhan perangkat lunak dari tahap analisis ke desain. Desain yang dibuat berupa sketsa desain aplikasi dengan menggunakan UML.

c) Implementasi

Setelah desain dibuat, tahap selanjutnya yaitu membuat atau mengembangkan aplikasi perangkat lunak yaitu aplikasi yang menggunakan teknologi Augmented Reality.

d) Pengujian

Pada tahap pengujian, verifikasi dan validasi aplikasi perangkat lunak dilakukan. Tahap pengujian digunakan untuk menemukan kesalahan atau debug pada saat pembuatan aplikasi.

e) Pemeliharaan

Tahap terakhir dari model waterfall ini adalah tahapan pemeliharaan. Proses instalasi produk dan pemeliharaan dilakukan dalam tahap pemeliharaan.

3. Instrumental Penelitian

Instrumen yang akan di teliti terkait sistem pemesanan lapangan yaitu:

1. Sistem pemesanan online lapangan futsal

Sistem pemesanan online ini merupakan sistem yang dilakukan tanpa harus mendatangin tempat penyewaan lapangan.

2. Sistem lihat jadwal lapangan

Sistem jadwal lapangan merupakan hasil dari pemesanan online. Dimana menampilkan jadwal - jadwal lapangan yang masih tersedia dan sudah penuh.

3. Sistem pembayaran lapangan futsal online

Sistem pembayaran lapangan ini menampilkan penyewa yang sudah melakukan deposito dan akan segera diproses pemesanannya.

Dalam menyelesaikan penelitian ini penulis menggunakan tiga instrumen penelitian seperti dibawah ini :

I. Data Pemesan Lapangan

Nama

Email

Tangal

Hari

Jam

II. Laporan Jadwal Lapangan

Nama tim

Jam bermain

Lama bermain

III. Laporan Pembayaran Lapangan

Deposito

Lunas

Tidak jadi

C. Teknik Pengumpulan Data

1. Pengamatan (Observation)

Pengamatan, penulis disini langsung mendatangi lapangan Kevin Futsal untuk melakukan pengecekan terhadap objek yang diteliti dilapangan.

2. Wawancara (Interview) 
Volume 2, Nomor 1, April 2021, halaman 60-74

https://jurnal.amikwidyaloka.ac.id/index.php/awl

jurnal@amikwidyaloka.ac.id / editor.jurnalwidya@gmail.com

Wawancara, Wawancara merupakan proses tanya jawab langsung kepada orang yang mengetahui tentang permasalahan yang sedang diamati. Penulis disini mewawancarai pemilik, karyawan serta pelanggan.

3. Studi Pustaka (Library Research)

Penulis melakukan pengumpulan bahan-bahan yang berkaitan dengan judul dengan membaca buku-buku. Sebagai referensi, peneliti juga memanfaatkan teknologi untuk membuka wawasan dan pengetahuan mengenai apa yang akan dikerjakan.

\section{Hasil dan Pembahasan (or Results and Analysis)}

A. Deskripsi Objek Penelitian

Deskripsi objek penelitian merupakan hal yang paling penting dilakukan oleh penulis, berikut deskripsi yang dilakukan oleh penulis pada objek yang dipilih oleh penulis yaitu pada Kevin Futsal.

B. Hasil Penelitian

Setelah dilakukan analisa maka tersusunlah hasil penelitian sebagai berikut :

1. Flowchart

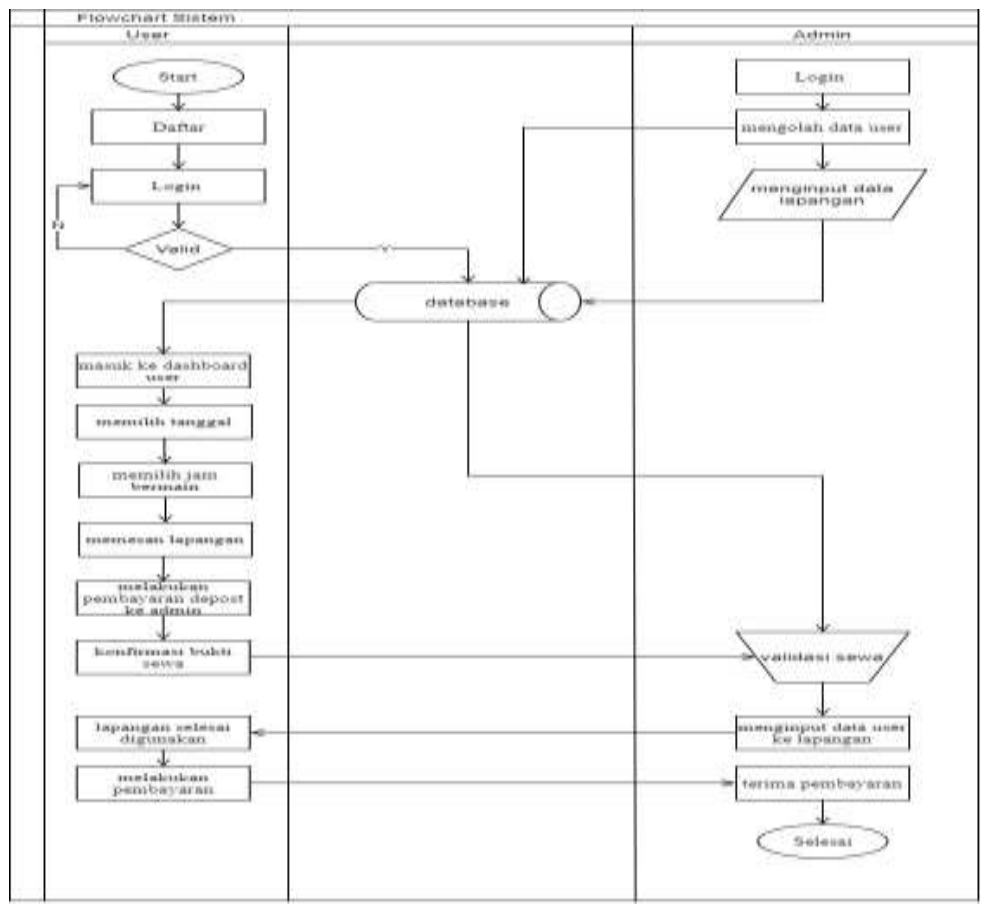

Gambar 2. Flowchart Sistem Usulan

Berdasarkan Gambar 2 terlihat sebuah flowchart, Langkah pertama yang di lakukan oleh user adalah daftar setelah itu user login dan memasukan email dan password, kemudian sistem akan melakukan validasi email, password tersebut jika berhasil akan masuk kedalam halaman dashboard user yang berisi tampilan kalender, setelah user memilih tanggal maka sistem akan menampilkan dashboard pilihan jam yang akan dipilih user untuk bermain user dan setelah itu user dapat melihat jumlah deposit yang sudah diisikan oleh admin sebagai tahap untuk membooking lapangan . setelah itu user dapat melihat jadwal yang sudah dipesan dan keluar dari aplikasi pelanggan Kevin Futsal. Sedangkan Admin diawali dengan login, setelah itu akan 
membawa Admin kedashboard lihat user dan booking yang sudah masuk ke jadwal lapangan, setelah itu Admin dilengkapi dengan tambah deposit dan hapus user dan jam bermain yang sudah usai, setelah sudah admin dapat keluar dari aplikasi.

2. Usecase Diagram Sistem

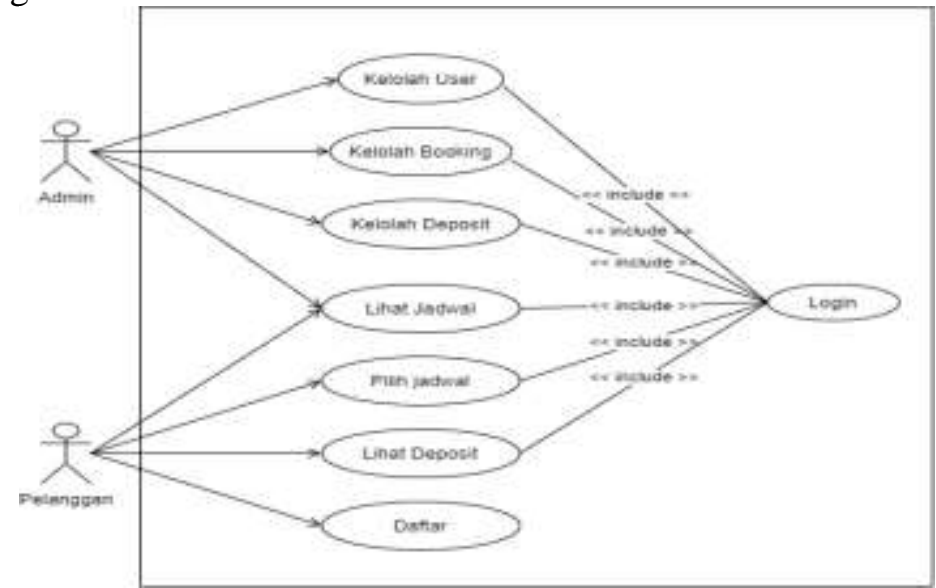

Gambar 3. Usecase Diagram Sistem

Berdasarkan gambar 3 terlihat sebuah Usecase Diagram dari Sistem, Terdapat 2 aktor yaitu aktor Admin dan Pelanggan. Admin bisa mengelola data user, booking, deposit dan lihat jadwal. Pelanggan diawali dengan daftarasetelah itu bisa lihat deposit, pilih jadwal dan lihat jadwal.

3. Class Diagram

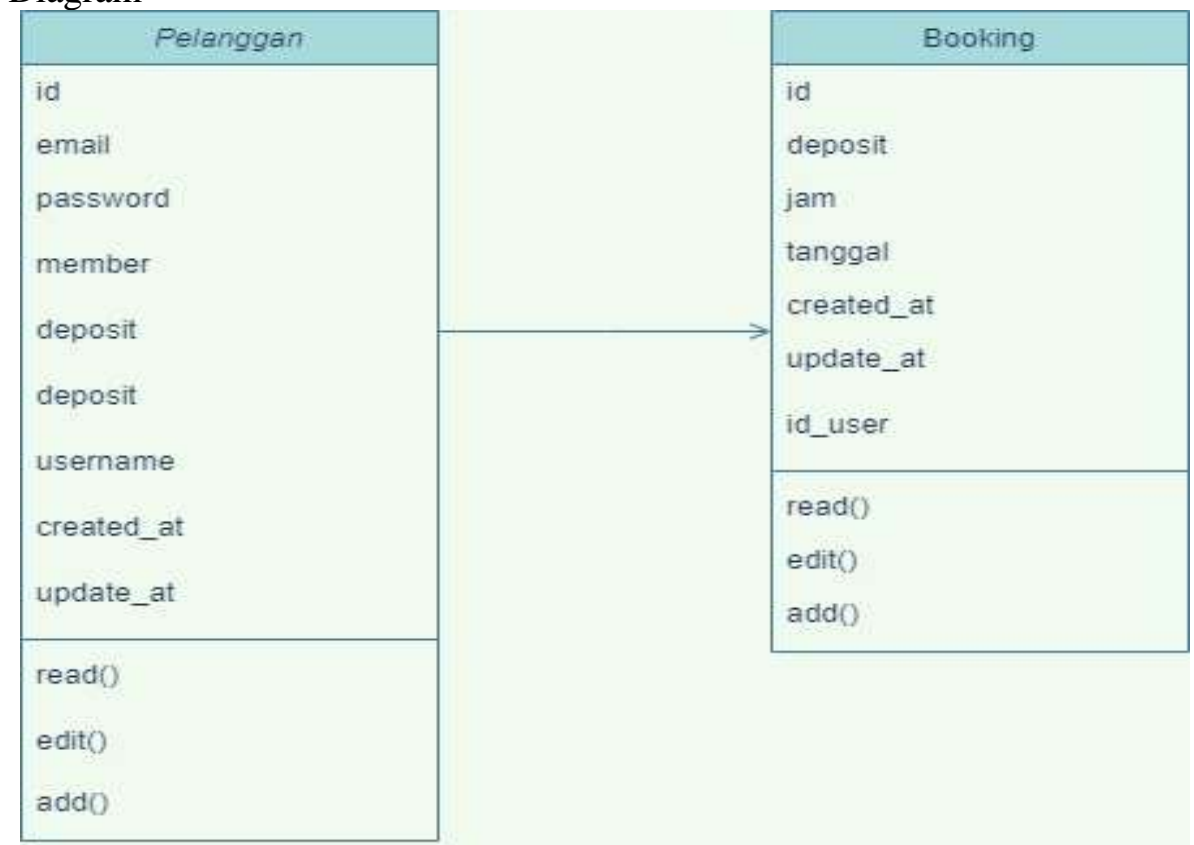

Gambar 4. Class Diagram Sistem

Berdasarkan gambar 4 terlihat sebuah Class Diagram yaitu bentuk database yang memiliki 2 tabel yaitu tabel Pelanggan dan Booking.

4. Activity Diagram Sistem 


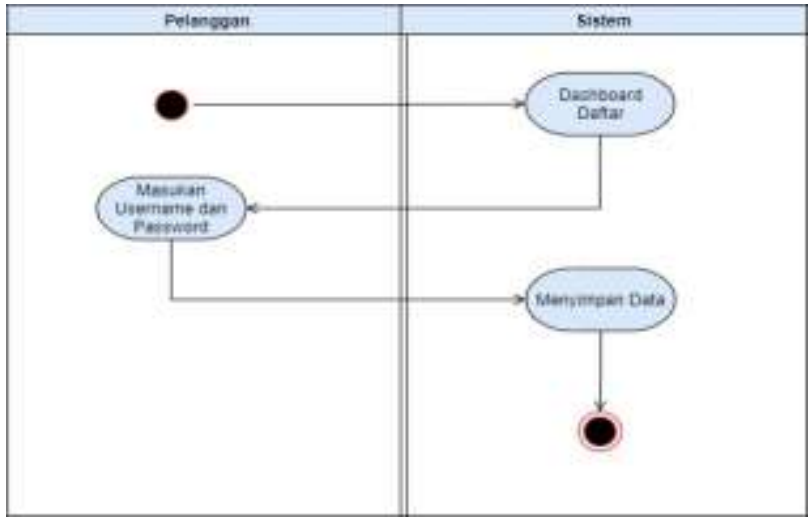

Gambar 5. Activity Diagram Daftar

Berdasarkan gambar 5 terlihat sebuah Activity Diagram Daftar, Langkah pertama yang di lakukan oleh aktor adalah masukan data, kemudian sistem akan menyimpan data, dan tugas karyawan untuk mengecek apakah data yang baru didaftarkan terkonfirmasi oleh sistem.

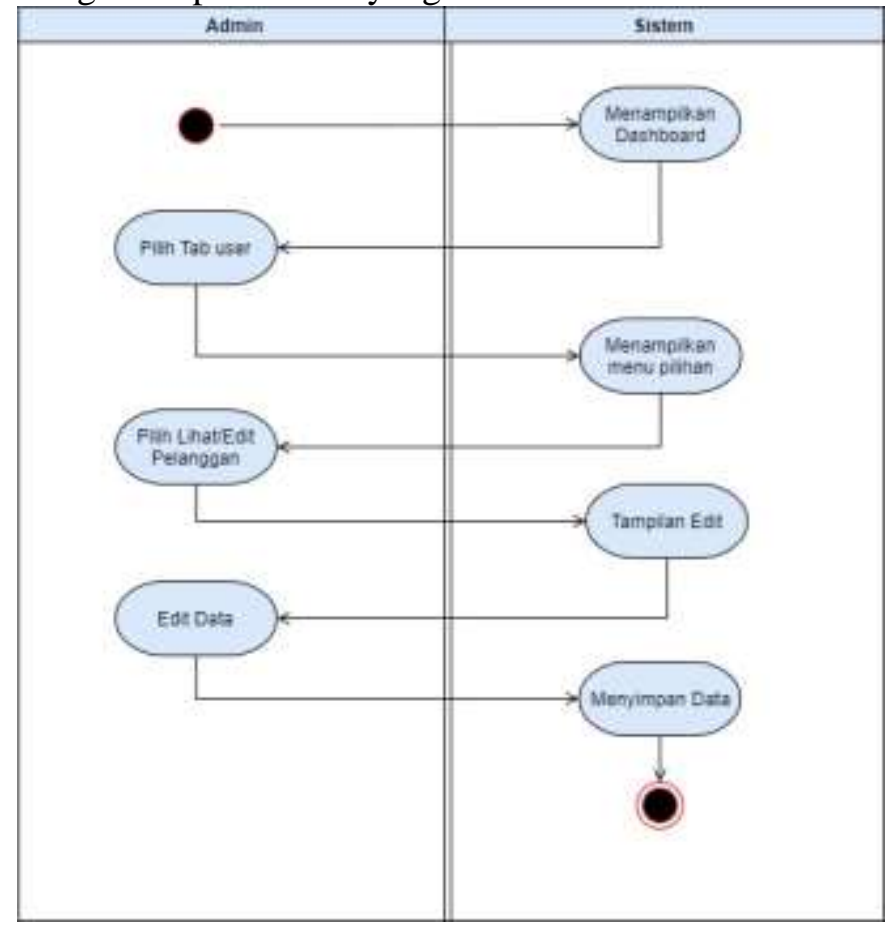

Gambar 6. Activity Diagram Admin Kelolah Pesanan

Berdasarkan gambar 6 terlihat sebuah Activity Diagram Admin Kelolah Pesanan, Langkah pertama yaitu sistem menampilkan dashboard yang dilanjut dengan admin memilih Tab User lalu sistem akan menampilkan Menu Pilihan setelah itu admin memilih Lihat Edit kemudian sistem akan menampilkan form Edit selanjutnya admin bisa mengedit data pelanggan setelah di Edit lanjut ke sistem untuk menyimpan data yang sudah diedit.

5. Sequence Diagram Sistem 
Volume 2, Nomor 1, April 2021, halaman 60-74

https://jurnal.amikwidyaloka.ac.id/index.php/awl

jurnal@amikwidyaloka.ac.id / editor.jurnalwidya@gmail.com

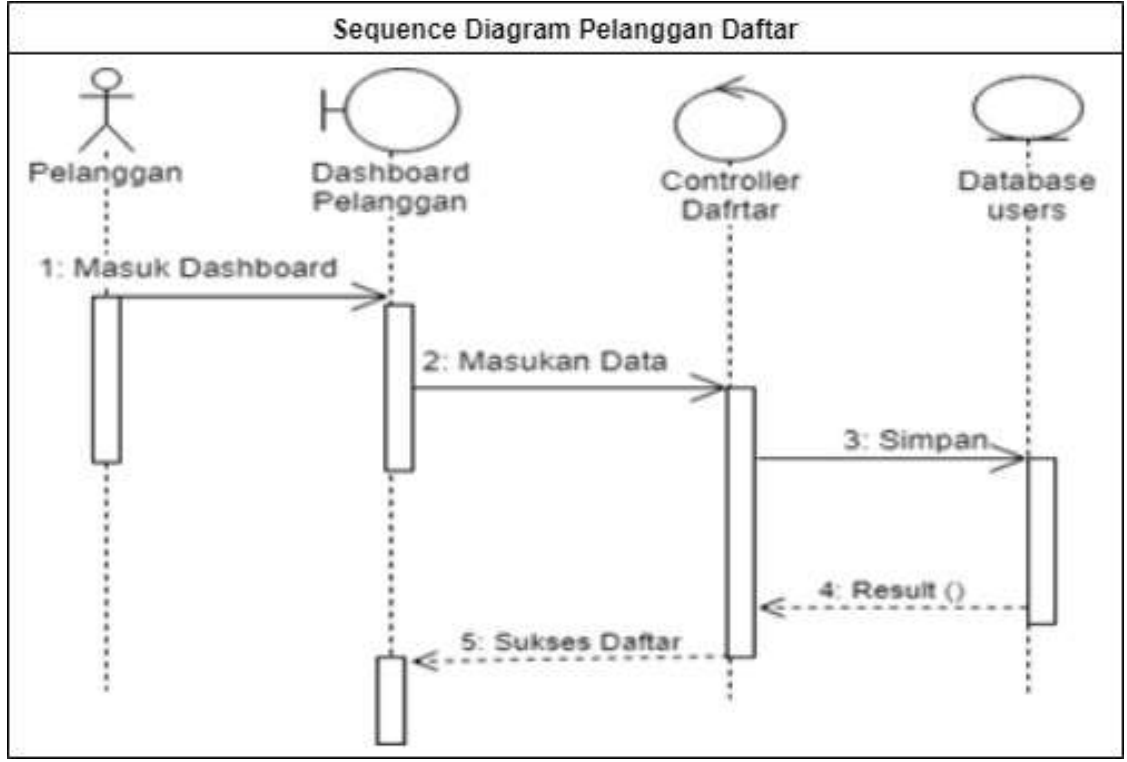

Gambar 7. Sequence Diagram Daftar

Berdasarkan gambar 7 terdapat Sequence Diagram Pelanggan Daftar, dapat dilihat aktor Pelanggan memasuki dashboard lalu dilanjut dengan memasukan data pelanggan seperti email, username dan password. Kemudian sistem akan menerima inputan dan menyesuaikan dengan data yang ada dalam database dan kemudian melakukan Result. Jika sudah benar maka sistem akan membawa Pelanggan ke halaman dashboard yang berarti sudah sukses terdaftar.

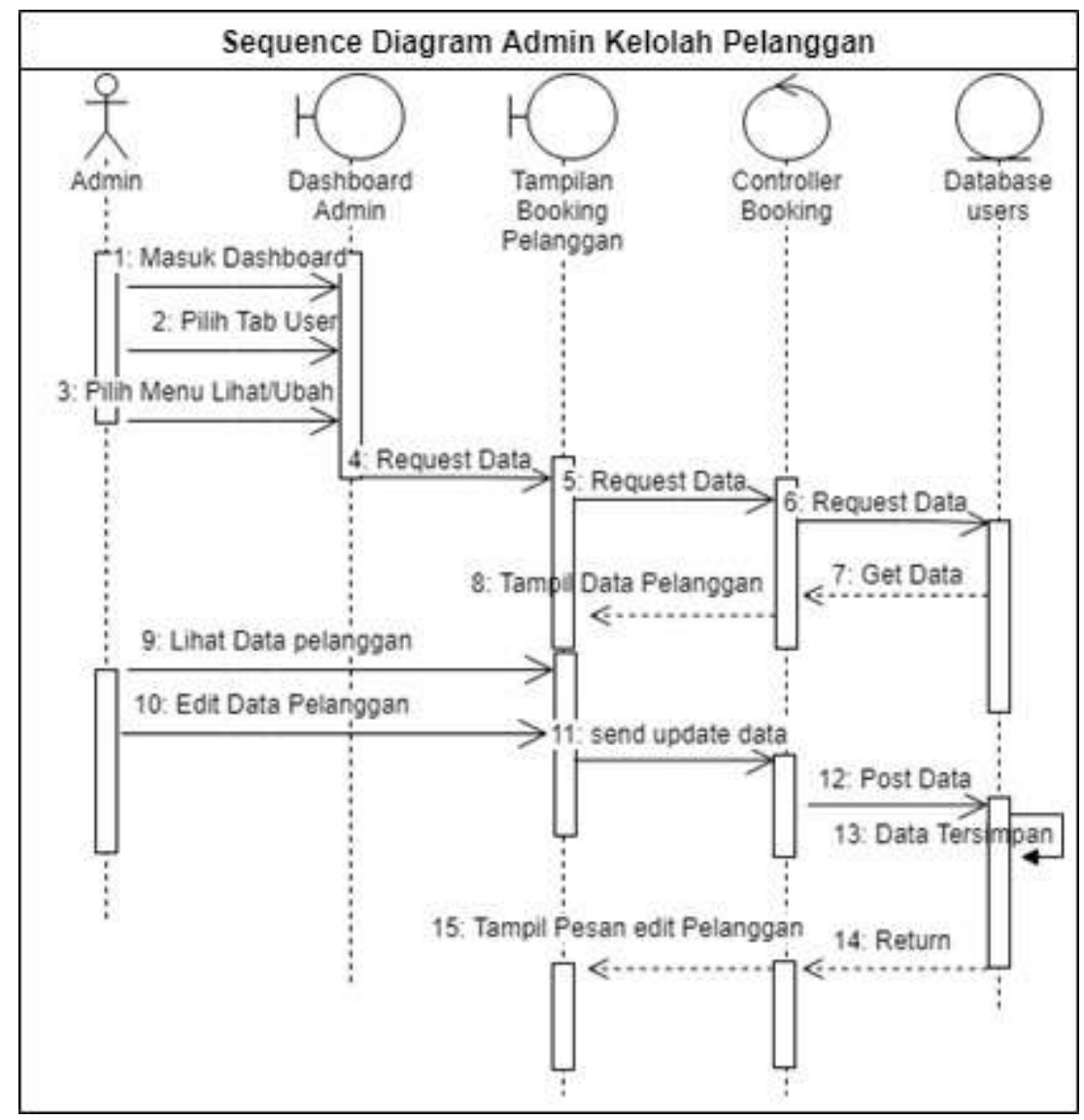


Gambar 8. Sequence Diagram Admin Kelolah Pesanan

Berdasarkan gambar 8 terdapat Sequence Diagram Admin Kelolah Pelanggan, dapat dilihat aktor masuk ke dashboard kemudian memilih Tab User dan memilih menu lihat dan ubah dan selanjutnya sistem akan menampilkan data sesuai dengan menu yang dipilih. Kemudian sistem request data ke tampilan booking pelanggan, controller booking dan database user. kemudian setelah mendapatkan data maka sistem akan membawa ke halaman tampilan data pelanggan.selanjutnya aktor melihat data pelanggan dan edit data pelanggan.kemudian setelah selesai mengedit data pelanggan, aktor mengirim update data ke database user, setelah data tersimpan maka sistem akan memberikan tampilan pesan edit pelanggan sukses.

C. Implementasi

Berikut ini adalah hasil implementasi dari perancangan yang dibuat:

1. Hasil Rancangan Tampilan Login Admin

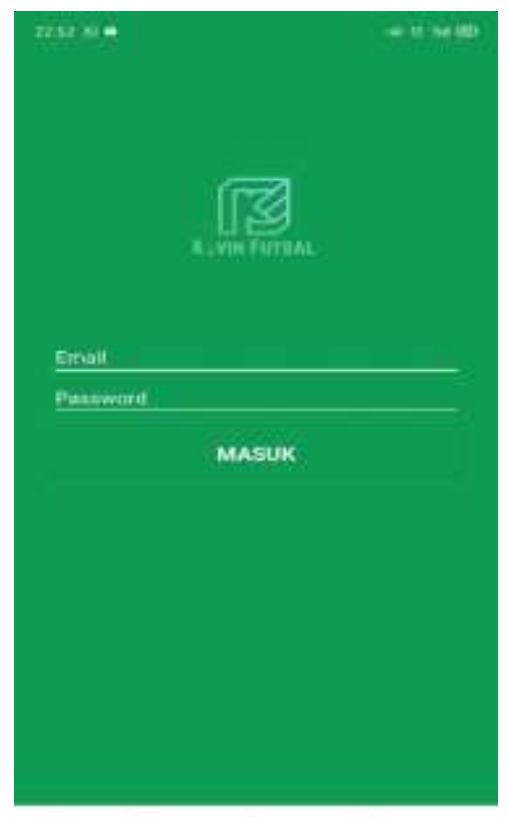

Gambar 9. Hasil Rancangan Tampilan Login Admin

2. Hasil Rancangan Tampilan Admin ke form User 


\section{Jurnal Widya}

Volume 2, Nomor 1, April 2021, halaman 60-74

P-ISSN: 2746-5411

e-ISSN: $x x x x-x x x x$

https://jurnal.amikwidyaloka.ac.id/index.php/awl

jurnal@amikwidyaloka.ac.id / editor.jurnalwidya@gmail.com

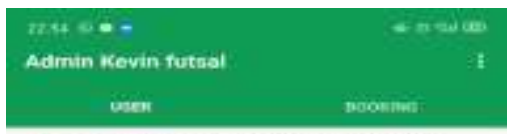

2 17570018 gatmik.jayakarta.ae.id

ㅇ fkripaturahmanz3œumail.oom

Gambar 10. Hasil Rancangan Tampilan Admin ke form User

3. Hasil Rancangan Tampilan Admin ke form Booking

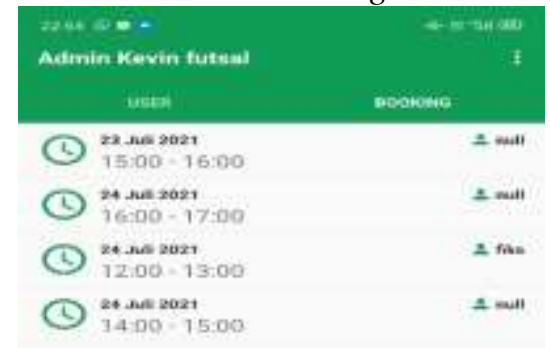

Gambar 11. Hasil Rancangan Tampilan Admin ke form Booking

4. Hasil Rancangan Tampilan Daftar Pelanggan 


\section{Jurnal Widya}

Volume 2, Nomor 1, April 2021, halaman 60-74

P-ISSN: 2746-5411

e-ISSN: $x x x x-x x x x$

https://jurnal.amikwidyaloka.ac.id/index.php/awl

jurnal@amikwidyaloka.ac.id / editor.jurnalwidya@gmail.com

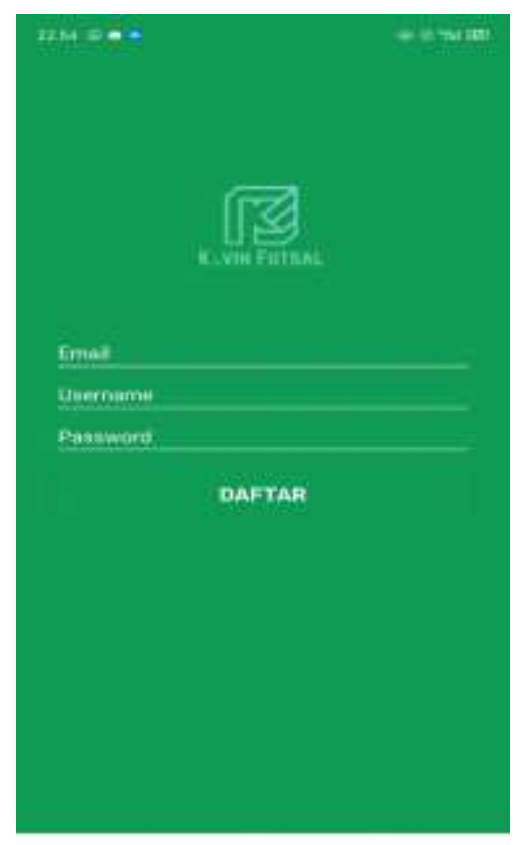

Gambar 12. Hasil Rancangan Tampilan Daftar Pelanggan

5. Hasil Rancangan Tampilan Login Pelanggan

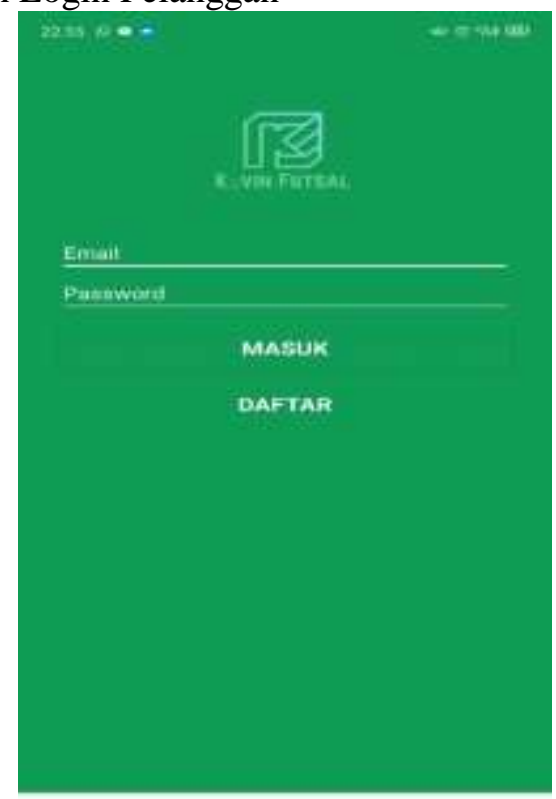

Gambar 13. Hasil Rancangan Tampilan Login Pelanggan

6. Hasil Rancangan Tampilan Pelanggan 
Volume 2, Nomor 1, April 2021, halaman 60-74

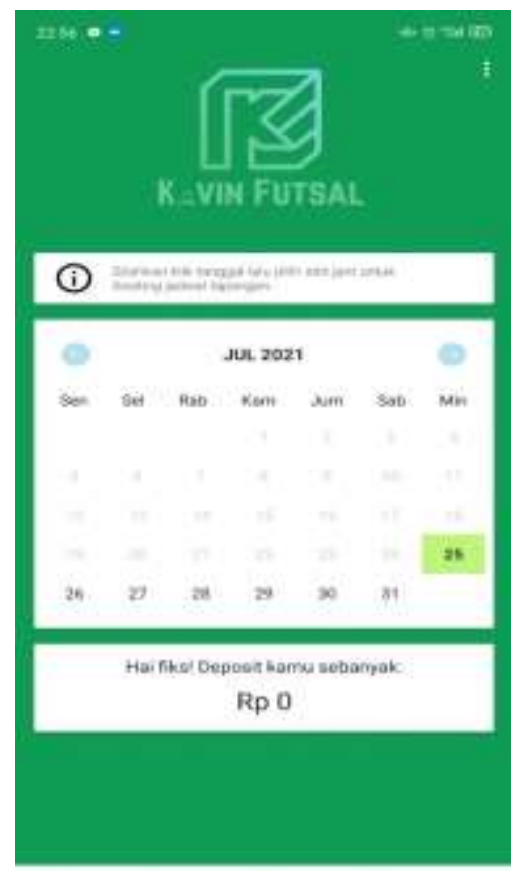

Gambar 14. Hasil Rancangan Tampilan Pelanggan

7. Hasil Rancangan Tampilan Booking Jadwal Pelanggan

\begin{tabular}{|c|c|}
\hline 27 Jull 2021 & $-8+\cos 6$ \\
\hline $00.00-10.00$ & 150=1 \\
\hline to:00-11:00 & 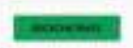 \\
\hline $11000-12: 00$ & 데."- \\
\hline $12000-13000$ & $=$ \\
\hline $13-00-14: 00$ & Denem \\
\hline $14: 00-15: 00$ & Fin \\
\hline $16=0-16: 00$ & - \\
\hline $16000-17: 00$ & =ninn \\
\hline $1700-10.00$ & 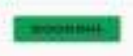 \\
\hline 10-00-1000 & rasment \\
\hline $10000-20: 00$ & 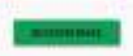 \\
\hline $2000-21: 00$ & $=$ \\
\hline
\end{tabular}

Gambar 15. Hasil Rancangan Tampilan Booking Jadwal Pelanggan

\section{Kesimpulan (or Conclusion)}

\section{A. Simpulan}

Berdasarkan dari hasil pembuatan "Aplikasi Booking Lapangan Futsal Berbasis Android" terdapat beberapa simpulan sebagai keberikut:

1. Aplikasi ini dapat meminimalisir terjadinya bentrokan jadwal booking dan dapat mempermudah dalam proses booking lapangan.

\section{c) (i) (-)


2. Aplikasi ini dapat memudahkan pelanggan untuk membooking tanpa harus datang ke lapangan terlebih dahulu karena dapat diakses kapanpun dan dimanapun dengan mudah dan cepat prosesnya.

3. Aplikasi ini dapat memudahkan karyawan kevin futsal dalam merekap data pelanggan karena sudah tersimpan di database.

B. Saran

Untuk perkembangan lebih lanjut, penulis memberi saran untuk dapat menambahkan fitur fitur yang berlum terealisasikan oleh penulis sebagi berikut:

1. Perlu ditambahkan fitur notifikasi utnuk pemesanan.

2. Perlu ditambahkan fitur chat dengan admin/karyawan yang sedang berjaga

3. Karena aplikasi ini hanya dapat digunakan saat menggunakan data handphone atau handphone sedang online maka dari itu perlu adanya penambahan aplikasi ini bisa berjalan saat sedang offline.

4. Belum dilengkapi dengan metode pembayaran online.

\section{Referensi (Reference)}

[1] F. Dania, "Rancang Bangun Aplikasi Pendataan Kompensasi Bagi Mahasiswa Teknik Telekomunikasi Berbasis Android.," Politeknik Negeri Sriwijaya, 2018.

[2] A. Ikhwan, M. A. Badruzaman, A. Khoir, and M. Muslihudin, "Implementasi Aplikais Penghafal Huruf Berbasis," J. Pendidik. Guru Madrasah Ibtidaiyah Al-Multazam JPGMI, vol. 4, no. 1, pp. 23-32, 2018.

[3] G. E. Atmodjo, "Preferensi Konsumen Terhadap Merek Smartphone Berdasarkan Sistem Operasi," Universitas Atma Jaya Yogyakarta, 2016.

[4] H. Kusniyati and N. S. Pangondian Sitanggang, "Aplikasi Edukasi Budaya Toba Samosir Berbasis Android," J. Tek. Inform., vol. 9, no. 1, pp. 9-18, 2016, doi: 10.15408/jti.v9i1.5573.

[5] A. Safitri and E. S. Nagara, "APLIKASI MOBILE LEARNING PADA MATA PELAJARAN EKONOMI KELAS X BERBASIS ANDROID,” vol. 3, no. 1, pp. 9-16, 2021.

[6] Benni Triyono, Sri Purwanti, Verdi Yasin (2017) "Rekayasa Perangkat Lunak Sistem Informasi Pengiriman Dan Penerimaan Surat Atau Paket Berbasis Web", Journal of Information System, Applied, Management, Accounting and Research, e-ISSN: 2598-8719. p-ISSN: 2598-8700.Vol.1 No.1 (30 Desember 2017) p46-53 http://iournal.stmikjayakarta.ac.id/index.php/iisamar/article/view/12

[7] Julinda Maya Paramudita, Verdi Yasin (2019) "Perancangan Aplikasi Sistem Penyewaan Alat Berat (studi kasus: PT. Jaya Alam Sarana Jakarta) “, Journal of Information System, Applied, Management, Accounting and Research, e-ISSN: 2598-8719. p-ISSN: 2598-8700.Vol.3 No.1 (20 Februari 2019) p2329 http://journal.stmikjayakarta.ac.id/index.php/iisamar/article/view/73

[8] Muryan Awaludin, Verdi Yasin (2020) "Application Of Oriented Fast And Rotated Brief (Orb) And Bruteforce Hamming In Library Opencv For Classification Of Plants", Journal of Information System, Applied, Management, Accounting and Research, e-ISSN: 2598-8719. p-ISSN: 2598-8700.Vol.4 No.3 (14 Agustus 2020) p51-59 http://journal.stmikjayakarta.ac.id/index.php/jisamar/article/view/247

[9] Ifan Junaedi, Dimas Abdillah, Verdi Yasin (2020) "Analisis Perancangan Dan Pembangunan Aplikasi Business Intelligence Penerimaan Negara Bukan Pajak Kementerian Keuangan RI", Journal of Information System, Applied, Management, Accounting and Research, e-ISSN: 2598-8719. p-ISSN: 2598-8700.Vol.4 No.3 (14 Agustus 2020) p88-101 http://journal.stmikjayakarta.ac.id/index.php/iisamar/article/view/249

[10] Verdi Yasin (2012) 'Rekayasa Perangkat Lunak Berorientasi Objek”, Penerbit: Mitra Wacana Media, Jakarta-Indonesia.

[11] Anis Rohmadi, Verdi Yasin (2020) “Desain Dan Penerapan Website Tata Kelola Percetakan Pada CV Apicdesign Kreasindo Jakarta Dengan Metode Prototyping", Journal of Information System, Informatics and Computing. E-ISSN: 2597-3673 (Online), P-ISSN: 2579-5201 (Print) Vol. 4 No.1, June 22, 2020. Pp.70-85 http://journal.stmikjayakarta.ac.id/index.php/jisicom/article/view/210

[12] Septian Cahyadi, Verdi Yasin, Mohammad Narji, Anton Zulkarnain Sianipar (2020) "Perancangan Sistem 
Informasi Pengiriman Dan Penerimaan Soal Ujian Berbasis Web ( Studi Kasus: Fakultas Komputer Universitas Bung Karno)", Journal of Information System, Informatics and Computing. E-ISSN: $2597-$ 3673 (Online), P-ISSN: 2579-5201 (Print) Vol. 4 No.1, June 22, 2020. Pp.1-16 http://journal.stmikjayakarta.ac.id/index.php/jisicom/article/view/199

[13] Ifan Junaedi, Ndaru Nuswantari, Verdi Yasin (2019) “Perancangan Dan Implementasi Algoritma C4.5 Untuk Data Mining Analisis Tingkat Risiko Kematian Neonatum Pada Bayi", Journal of Information System, Informatics and Computing. E-ISSN: 2597-3673 (Online), P-ISSN: 2579-5201 (Print) Vol. 3 No.1, February 13, 2019. Pp.29-44. http://journal.stmikjayakarta.ac.id/index.php/jisicom/article/view/203

[14] Verdi Yasin, Anindra Ramdhan Nugraha, Muhammad Zarlis, Ifan Junaedi (2018) "Smart System Of Fast Internet Access Development Using Backbone Network Method", Journal of Information System, Informatics and Computing. E-ISSN: 2597-3673 (Online), P-ISSN: 2579-5201 (Print) Vol. 2 No. 2 , December 31, 2018. Pp.26-34. http://journal.stmikjayakarta.ac.id/index.php/jisicom/article/view/198

[15] Ito Riris Immasari, Verdi Yasin (2019) “Penggunaan Metode Analytic Hierarchy Process Untuk Menganalisis Faktor-Faktor Yang Mempengaruhi Pemilihan Calon Legislatif Di Dprd li Kota Tangerang”, Journal of Information System, Informatics and Computing. E-ISSN: 2597-3673 (Online), P-ISSN: 2579-5201 (Print) Vol. 3 No. 2, December 10, 2019. Pp.53-58. http://journal.stmikjayakarta.ac.id/index.php/jisicom/article/view/139

[16] Verdi Yasin, Muhammad Zarlis, Tulus, Erna Budhiarti Nababan, Poltak Sihombing (2019) "Rancangan Miniatur Otomatisasi Bel Listrik Pada Gerbang Pintu Menggunakan Microkontroler Atmega8535", Journal of Information System, Informatics and Computing. E-ISSN: 2597-3673 (Online), P-ISSN: 2579-5201 (Print) Vol. 3 No. 1, February 13, 2019. Pp.13-20 http://journal.stmikjayakarta.ac.id/index.php/jisicom/article/view/68

[17] Anggeri S. Nurjaman, Verdi Yasin (2020) "Konsep Desain Aplikasi Sistem Manajemen Kepegawaian Berbasis Web Pada PT. Bintang Komunikasi Utama ”, Journal of Information System, Informatics and Computing. E-ISSN: 2597-3673 (Online), P-ISSN: 2579-5201 (Print) Vol. 4 No. 2, December 28, 2020. Pp.143-174 http://journal.stmikjayakarta.ac.id/index.php/jisicom/article/view/363

[18] Verdi Yasin, Azhar Ahmad Riza, Rumadi Hartawan (2017) "Pengembangan Aplikasi Pemulihan Layanan Bencana Sistem Informasi Peneriman Negara Bukan Pajak Online Di Lingkungan Kementerian Keuangan Republik Indonesia”, Journal of Information System, Informatics and Computing. EISSN: 2597-3673 (Online), P-ISSN: 2579-5201 (Print) Vol. 1 No. 1, September 20, 2017. Pp.33-56. http://journal.stmikjayakarta.ac.id/index.php/jisicom/article/view/4

[19] Verdi Yasin (2021) "Penerapan sistem kegiatan belajar dan mengajar dalam instrumen Sertifikasi Dosen Profesional menggunakan metode SMART”, Tridharmadimas: Jurnal Pengabdian Kepada Masyarakat Jayakarta,E-ISSN: 2798-8295 (Online), P-ISSN: 2798-8554 (Print) page: 37-55 DOI: 10.52362/tridharmadimas.v1i1.501 URL: http://journal.stmikjayakarta.ac.id/index.php/tridharmadimas/article/view/501 